\title{
НАЦІОНАЛЬНА БЕЗПЕКА УКРАЇНИ ЯК ОБ'ЄКТ ПОСЯГАННЯ ПРИ КОРУПЦІЙНОМУ ПІДКУПІ
}

Михайлов М. В.

\begin{abstract}
У статmі представлено обгрунтування нового розуміння об'єкту посягання в разі вчинення будьякого з видів корупційного підкупу. У зв'язку з тим, що корупційний підкуп $\epsilon$ родовим поняттям до низки кримінальних правопорушень, натепер неможливо говорити про його склад, як склад злочину чи якогось одного виокремленого кримінального правопорушення. Водночас досліджені автором раніше види корупційного підкупу свідчать, що ті кримінальні правопорушення, які були ним віднесені до корупційного підкупу, мають більшість спільних об'єктивних та суб'єктивних ознак, що дає змогу говорити про склад корупційного підкупу, яким узагальнюються конститутивні та кваліфікуючі ознаки окремих його видів. Зокрема, до кримінальних правопорушень, які варто охоплювати поняттям «корупційний підкуп», автор відносить діяння, відповідальність за які передбачена сmamтями 354, 368, 368-3, 368-4, 369, 369-2, 369-3, cm. 370 КК України. У статті обґрунтовується доцільність відходу від ідеології позитивізму в кримінально-правовій доктрині, а також наближення до концепції соціального натуралізму, що дасть змогу змінити ефективність наукових досліджень та наблизити їх до реальних проблем суспільства та держави. Для визначення родового об'єкту корупційного підкупу за основоположний концепт автором вибрано соціальний натуралізм, який дозволяє виявити істинні, корінні характеристики цього виду злочинності. У статmі обстоюється думка, що використані науковцями позитивістські підходи призвели до еклектичного поєднання окремих сфер державного управління, при цьому цінність або правове благо, якому дійсно заподіюється шкода в разі корупційного підкупу, так і залишилась поза їхньою увагою. У результаті зроблено висновок, що протидія корупції в Україні має здійснюватися за найвищим ступенем nріоритетності, а всеосяжність шкоди від корупційних проявів дає підстави стверджувати, що родовим об'єктом корупційного підкупу має визнаватися таке правове благо, як національна безпека України. Виходячи з натуралістичної позиції, зроблено висновки щодо безпосереднього об'єкту видів корупційного підкупу.
\end{abstract}

Ключові слова: корупція, підкуп, неправомірна вигода, корупційний підкуп, кримінальна відповідальність, соціальний натуралізм.
Mykhailov M. V. National security of Ukraine as an object of attraction in corruption bribery

The article presents a rationale for a new understanding of the object of encroachment in the commission of any type of corruption bribery. Due to the fact that corruption bribery is a generic concept for a number of criminal offenses, it is currently not possible to speak of its composition as a corpus delicti or any single isolated criminal offense. At the same time, the author's previously investigated types of corruption bribery show that those criminal offenses that he attributed to corruption bribery have the most common objective and subjective features, which allows us to talk about the composition of corruption bribery, which summarizes the constitutional and qualifying features some of its species. In particular, the author refers to criminal offenses, which should be covered by the concept of corruption bribery, acts for which liability is provided by Articles 354, 368, 368-3, 368-4, 369, 369-2, 369-3, Art. 370 of the Criminal Code of Ukraine. The article substantiates the expediency of moving away from the ideology of positivism in criminal law doctrine, as well as approaching the concept of social naturalism, which will change the effectiveness of research and bring them closer to the real problems of society and the state. To define the generic object of corruption bribery, the author chose social naturalism as the basic concept, which allows to reveal the true, fundamental characteristics of this type of crime. The article argues that the positivist approaches used by scholars have led to an eclectic mix of different areas of public administration, while the value or legal benefit that is really harmed by corrupt bribery has gone unnoticed. As a result, it is concluded that the fight against corruption in Ukraine should be carried out at the highest priority, and the comprehensiveness of the damage from corruption suggests that the generic object of corruption bribery should be recognized as a legal good as national security of Ukraine. Based on the naturalistic position, conclusions were drawn about the direct object of the types of corrupt bribery.

Key words: corruption, bribery, illegal profit, corrupt bribery, criminal liability, social naturalism.

Постановка проблеми та іï актуальність. Обов'язковим елементом дослідження 
кримінальної відповідальності за будь-яке кримінальне правопорушення $\epsilon$ аналіз ознак його складу злочину. Не є виключенням й дослідження кримінальної відповідальності за корупційний підкуп. Розгляд і надання характеристики об'єктивним та суб'єктивним елементам складу злочину уможливить більш ґрунтовне розуміння як самого поняття корупційного підкупу, так і його форм та видів. При цьому варто зауважити, що корупційний підкуп відсутній як виокремлене суспільно небезпечне діяння в Кримінальному кодексі України. Як зазначалось вище, це родове поняття, яким охоплюється певна сукупність корупційних та пов'язаних з корупцією кримінальних правопорушень, що поєднує в собі випадки надання/отримання (та інші передбачені кримінальним законодавством дії) неправомірної вигоди як форм діяння в цих кримінальних правопорушеннях. У попередніх публікаціях нами було обґрунтовано введення цього поняття до законодавчого та правозастосовного вжитку і підтверджено проведеним експертним анкетуванням.

У зв'язку з тим, що корупційний підкуп є родовим поняттям до низки кримінальних правопорушень, натепер неможливо говорити про його склад, як склад злочину чи якогось одного виокремленого кримінального правопорушення. Водночас досліджені нами раніше види корупційного підкупу свідчать, що ті кримінальні правопорушення, які були нами віднесені до корупційного підкупу, мають більшість спільних об'єктивних та суб'єктивних ознак, що дає змогу говорити про склад корупційного підкупу, яким узагальнюються конститутивні та кваліфікуючі ознаки окремих його видів. Як уже зазначалось, до кримінальних правопорушень, які варто охоплювати поняттям «корупційний підкуп», варто віднести діяння, відповідальність за які передбачена статтями 354, 368, 368-3, 368-4, 369, 369-2, 369-3, ст. 370 КК України.

Як зазначається в правничій науковій літературі, зазвичай відправною точкою для з'ясування складу будь-якого злочину $є$ його об'єкт. Зазначене насамперед пояснюється тим, що об'єкт злочину зумовлює виникнення кримінально-правової заборони, відіграє вирішальну роль у встановленні характеру суспільної небезпечності діяння, $\epsilon$ основою побудови структури Особливої частини КК України. Отже, значення правильного розуміння сутності об'єкта злочину важко переоцінити [1, с. 59].

Аналіз останніх досліджень і публікацій. Особливості кримінально-правової протидії корупції в Україні $\epsilon$ предметом досліджень таких науковців, як П.П. Андрушко, М.Г. Арманов, В.В. Березнер, О.О. Дудоров, О.О. Кваша, В.М. Киричко, В.М. Куц, М.І. Мельник, Д.Г. Михайленко, В.О. Навроцький, А.С. Політова, А.В. Савченко, B.І. Осадчій, М.І. Хавронюк, Н.М. Ярмиш та інших.

Метою статті $\epsilon$ висвітлення результатів дослідження щодо родового та безпосереднього об'єкта корупційного підкупу як родового поняття до всіх видів кримінально-караного підкупу, що визначені в законі як корупційні кримінальні правопорушення.

Виклад основного матеріалу. Як зазначається в літературі, об'єкт злочину може бути введений до складу злочину шляхом закріплення правової норми у відповідному розділі Особливої частини [2, с. 179]. Такий об'єкт, який є властивим для певної групи злочинів, виокремленої в самостійний розділ Особливої частини Кримінального кодексу, називають родовим.

Під час дослідження родового об'єкту корупційного підкупу постають певні труднощі, пов'язані насамперед із тим, що норми, якими передбачено кримінальну відповідальність за окремі види корупційного підкупу, поміщені в різні розділи Особливої частини Кодексу. Так, стаття 354 КК України, якою передбачена відповідальність за підкуп працівника підприємства, установи чи організації, знаходиться в XV Розділі Особливої частини Кримінального кодексу «Кримінальні правопорушення проти авторитету органів державної влади, органів місцевого самоврядування, об'єднань громадян та кримінальні правопорушення проти журналістів». Решта визначених нами видів корупційного підкупу згруповані в Розділі XVII Особливої частини Кодексу «Кримінальні правопорушення у сфері службової діяльності та професійної діяльності, пов'язаної з наданням публічних послуг».

Значна частина наукової спільноти України тяжіє до думки, що стаття 354 КК України поміщена в такий розділ Особливої частини Кримінального кодексу України, який невірно характеризує іiі родовий об'єкт, що детермінує подальші помилкові висновки щодо безпосереднього об'єкту цього злочину, характеру суспільної небезпеки, наслідків тощо. Водночас усі спроби знайти їй місце в існуючій системі Особливої частини КК України $\epsilon$ безрезультатними або поверховими. Зазначене дозволяє стверджувати, що авторитет органів державної влади, органів місцевого самоврядування та об'єднань громадян називати родовим об'єктом цього злочину є помилкою. 
Якщо ж говорити про родовий об'єкт інших кримінальних правопорушень, які були віднесені до корупційного підкупу, то їх знаходження в одному розділі Особливої частини Кримінального кодексу України спрощує його визначення.

У кримінально-правовій науці вже неодноразово висловлювались позиції щодо родового об'єкту злочинів у сфері службової діяльності, які зазнавали певної кореляції, пов'язаної із законодавчими змінами. Однак загалом позиції щодо розуміння родового об'єкта цієї категорії злочинів, у тому числі й тих діянь, які були нами віднесені до корупційного підкупу, мають багато спільних рис.

Так О.О. Дудоров підкреслював, що тією соціальною цінністю, яка потребує з боку держави особливого правового захисту, в тому числі за допомогою кримінально-правових норм про службові злочини, $\epsilon$ нормальна (правильна) робота з функціонування державної управлінської сфери як сфери діяльності публічних службових осіб [3, с. 15].

Досліджуючи родовий об'єкт підкупу особи, який надає публічні послуги, О.С. Перешивко доходить висновку, що родовим об'єктом цього злочину $\epsilon$ правовідносини, що забезпечують визначений у законодавстві належний порядок здійснення діяльності службових осіб, та правовідносини, які забезпечують належний порядок здійснення особами професійної діяльності, пов'язаної з наданням публічних послуг, у межах наданих їм повноважень та у спосіб, передбачений законом [4, с. 110].

Водночас окремі науковці зазначають, що з назви Розділу XVII Особливої частини КК України неможливо зробити висновок про родовий об'єкт цієї категорії злочинів. Зокрема, М.Г. Арманов указує, що ті назви розділів Особливої частини Кодексу, які вказують на сферу їх вчинення, не зазначають, проти чого спрямована певна група злочинів, це у свою чергу детермінує появу труднощів у з'ясуванні їхнього об'єкта та може створити труднощі в їх кваліфікації [5, с. 53].

Узагальнюючи наукові позиції щодо родового об'єкта вказаної групи злочинів, можна стверджувати, що він законодавством не визначений. У свою чергу доктрина кримінального права, відштовхуючись від назви цього Розділу: «Кримінальні правопорушення у сфері службової діяльності та професійної діяльності, пов'язаної з наданням публічних послуг», пов'язує визначення родового об'єкту зі сферами діяльності, переліченими в цій назві. При цьому як родовий об'єкт іноді визнача- ють саму діяльність, іноді - порядок її здійснення. В окремих випадках цей елемент складу злочину ідентифікують як окремі права осіб, яким може заподіюватись шкода неналежним виконанням вказаних професійних чи службових обов'язків.

Наведене дозволяє стверджувати, що кримінальні правопорушення згруповані в Розділі XVII Особливої частини Кримінального кодексу не за їхнім родовим об'єктом, а саме за сферами їх вчинення. Це у свою чергу говорить про недоцільність та високу ймовірність безрезультатності наукових пошуків щодо визначення їх родового об'єкта. Водночас розподіл цих злочинів на групи уможливить виокремлення родового об'єкта конкретної групи. Тому, на нашу думку, цілком справедливо говорити не про родовий об'єкт кримінальних правопорушень у сфері службової діяльності та професійної діяльності, пов'язаної з наданням публічних послуг, а про родові об'єкти окремих груп цих злочинів, зокрема про родовий об'єкт корупційного підкупу. При цьому не варто забувати, що до останнього нами віднесено й злочин, передбачений ст. 354 КК України «Підкуп працівника підприємства, установи чи організації».

Використання чинної системи кримінального законодавства для визначення родового об'єкту корупційного підкупу, на нашу думку, $є$ недоцільним та не зможе дати більш точного результату, аніж ті, які вже були отримані дослідниками та наведені вище. Лише відхід від ідеології позитивізму в кримінально-правовій доктрині, а також наближення до концепції соціального натуралізму здатні змінити ефективність наукових досліджень та наблизити їх до реальних проблем суспільства та держави.

Академік О.М. Костенко називає позитивізм хворобою та вказує, що взагалі «позитивізм» можна визначити як світоглядну ідеологію, що полягає у прийнятті видимості за дійсність. Вилікуватися від «хвороби» позитивізму можна лише за допомогою доктрини, яка за видимістю дозволить відкрити дійсність. Як, зокрема, свідчить досвід епохи Просвітництва XVII - XVIII ст., такою доктриною $€$ доктрина, заснована на натуралістичному світогляді, відповідно до якої критерієм, за яким дійсність слід відрізняти від видимості, $\epsilon$ закони Природи: дійсним $€$ те, що узгоджується із законами Природи, а те, що не узгоджується, $\epsilon$ лише видимістю [6, с. 192-193].

Для визначення родового об'єкту корупційного підкупу необхідним $\epsilon$ звернення до кримінологічних досліджень самої корупції, якими визначається суспільна небезпечність цього явища. 
При цьому основоположним концептом $є$ так само соціальний натуралізм, який дозволяє виявити істинні, корінні характеристики цього виду злочинності.

У своїй статті «Корупція в Україні у світлі політичної кримінологї̈» академік О.М. Костенко проаналізував корупцію як один із видів девіантної поведінки, висвітлив її особливості в Україні та визначив основні напрями протидії цьому явищу. Так, зокрема, вчений зазначає, що слово «корупція» означає зловживання, яке полягає у використанні законодавства чи публічної влади в приватних інтересах одних людей на шкоду приватним інтересам інших. Законодавство і публічна влада - це інструменти, призначені для забезпечення порядку в суспільному житті, заснованого на природних законах. Цей порядок $є$ основою справедливості в розподілі соціальних благ. Зловживання законодавством і публічною владою $\epsilon$ свавіллям, яке полягає в порушенні порядку, заснованого на природних законах суспільного життя людей, а отже, і в порушенні соціальної справедливості. Тому корупція - це не лише порушення політичного, економічного, правового порядку в суспільстві, а й аморальний вчинок, гріх [7, с. 49].

До сучасних спроб розроблення кримінально-правової протидії корупції цілком, на нашу думку, можна віднести такий вислів академіка О.М. Костенка: «Неврахування закономірностей існування корупції кризового типу в Україні призводить до волюнтаризму в протидії їй (зокрема, до законодавчого і політичного волюнтаризму, який проявляється у безсистемному реформуванні інституцій кримінальної юстиції)» [7, с. 50]. Саме такий результат можна спостерігати під час аналізу спроб визначення родового об'єкта кримінальних правопорушень, поміщених до XVII Розділу Особливої частини Кримінального кодексу України, а точніше, відсутність такого результату. Використані науковцями позитивістські підходи, які були проілюстровані вище, призвели до еклектичного поєднання окремих сфер державного управління, при цьому цінність або правове благо, якому дійсно заподіюється шкода цими злочинами, зокрема корупційним підкупом, так і залишилась поза їхньою увагою.

Для наближення до природної сутності об'єкта злочинного посягання в разі корупційного підкупу варто враховувати, що кримінологічне бачення суспільної шкоди, яка заподіюється корупцією, сформовано з позицій соціального натуралізму.
Академік О.М. Костенко вказує, що корупція, порушуючи природні закони суспільного життя людей, $\epsilon$ кримінальною формою їх експлуатації. Різні блага, що стають предметом корупції, розподіляються між людьми не за природними законами суспільного життя, а за сваволею корупціонерів, які зловживають владою, наданими їм правами для того, щоб отримати певні блага, які не належать їм за законами соціальної природи. Тобто: корупція - це завжди «протиприродне» (всупереч законам соціальної природи) отримання благ одними за рахунок інших - і ніщо інше. Потерпають від корупції всі громадяни, крім, звичайно, самих корупціонерів. Наскільки вони протиприродно отримують неналежні їм блага, настільки на них лежить провина за посягання на добробут інших людей: скільки вони протиприродним чином отримали собі - стільки вони відібрали в інших [7, с. 52].

Цілком справедливим є твердження науковця, що корупція заподіює шкоду кожному, без вибору, не оминаючи жодного. Це дійсні масштаби цього негативного явища, які неможливо звести до окремого факту злочинної поведінки чи до певного порядку виконання професійних обов'язків у тій чи іншій сферах. Саме всеосяжність шкоди від такого явища, як корупція, актуалізує протидію йому на найвищих щаблях, як в окремій державі, так і в міжнародній співпраці. Окремі прояви корупції - конкретні акти протиправної, зазвичай злочинної, поведінки злилися у своєму суспільному існуванні, і вже не тільки заподіюють шкоду конкретному потерпілому чи порушують певний порядок управління. Кожен із цих проявів девіантної поведінки включається та формує корупцію як явище, підживлює їі існування, підсилює її та укорінює у свідомості громадян як норму. Саме в цьому і полягає суспільна небезпечність корупційного підкупу, я саме такі натуралістичні світоглядні позиції дають змогу визначити дійсний родовий об'єкт цієї групи кримінальних правопорушень.

У проекті Закону України «Про засади державної антикорупційної політики на 2020-2024 роки» корупція розглядається як ключова перешкода стабільному економічному зростанню та розбудові ефективних та інклюзивних демократичних інститутів, що прямо зазначено в пункті 1.2. цієї антикорупційної стратегії [8]. Пояснювальна записка до цього проекту містить результати ґрунтовних кримінологічних досліджень, які зумовлюють виведення антикорупційної протидії на новий рівень [9, с. 6-8]. 
Наведене дозволяє стверджувати, що протидія корупції в Україні має здійснюватися за найвищим ступенем пріоритетності. А проведені академіком О.М. Костенком кримінологічні дослідження та висновки щодо всеосяжності шкоди від корупційних проявів дають підстави стверджувати, що родовим об'єктом корупційного підкупу має визнаватись таке правове благо, як національна безпека України.

Відповідно до п. 9 ст. 1 Закону України «Про національну безпеку України» національна безпека України - це захищеність державного суверенітету, територіальної цілісності, демократичного конституційного ладу та інших національних інтересів України від реальних та потенційних загроз [10]. Конституцією України визначено, що Україна $є$ суверенна і незалежна, демократична, соціальна, правова держава (ст. 1), людина, іiі життя і здоров'я, честь і гідність, недоторканність і безпека визнаються в Україні найвищою соціальною цінністю (ст. 3), захист суверенітету і територіальної цілісності України, забезпечення ії економічної та інформаційної безпеки $\epsilon$ найважливішими функціями держави, справою всього Українського народу (ч. 1 ст. 17) [11]. Саме ці основоположні приписи Основного Закону набувають максимального ступеню декларативності через поширення корупції в Україні, зокрема у формі корупційного підкупу, що підтверджує спрямованість корупційного підкупу як кримінального правопорушення на заподіяння шкоди благам, які охоплюються поняттям «національна безпека України».

Твердження про те, що корупція становить загрозу національній безпеці України, не $\epsilon$ новим. Ще у 2016 році в підручнику «Глобальна та національна безпека» було зазначено, що корупція $\epsilon$ складником механізму експлуатації суспільства бюрократичними структурами. Якщо у провладної еліти та у широких верств населення переважає користолюбство та зневага до законодавства, корупція може перетворюватися на негативний i визначальний структуроутворюючий елемент повсякденного політичного та економічного життя суспільства. Головна загроза корупції полягає в тому, що вона перероджує державний апарат. Тому боротьба з корупцією $€$ одним із пріоритетів, що стоять перед українським суспільством [12, с. 859-864].

Однак дотепер у кримінально правовій науці національна безпека не розглядалась як об'єкт корупційних кримінальних правопорушень. На нашу думку, саме національна безпека становить родовий об'єкт корупційного підкупу. Виходячи з цієї натуралістичної позиції, необхідно робити висновки про безпосередній об'єкт кожного з видів корупційного підкупу.

У літературі зазначається, що корупція $\epsilon$ одним із факторів, які породжують низку небезпек, котрі можуть досить швидко призвести до руйнації соціальної системи (держави) [12, с. 39]. Складники цієї соціальної системи і $\epsilon$ безпосередніми об'єктами окремих видів корупційного підкупу. I на цьому рівні вони можуть визначатись як установлений законодавством порядок (система) державного управління в тій чи іншій сфері або порядок виконання службових, професійних чи інших обов'язків.

Висновки. Наведене дозволяє сформулювати висновки щодо розуміння об'єкта та предмета корупційного підкупу. Базуючись на натуралістичних світоглядних засадах щодо здійснення досліджень у кримінально-правовій сфері, враховуючи всеосяжність шкоди від такого явища, як корупція, необхідність актуалізації протидії йому на найвищих рівнях як в окремій державі, так і в міжнародній співпраці, обґрунтовано наукову позицію, згідно з якою родовим об'єктом корупційного підкупу має визнаватись таке правове благо, як національна безпека України. Доведено спрямованість корупційного підкупу як кримінального правопорушення на заподіяння шкоди благам, які охоплюються поняттям «національна безпека України».

Виходячи з цієї натуралістичної позиції, зроблено висновки щодо безпосереднього об'єкту кожного з видів корупційного підкупу. Оскільки корупція $\epsilon$ одним із факторів, які породжують низку небезпек, що можуть досить швидко призвести до руйнації соціальної системи (держави), то складники цієї соціальної системи і $\epsilon$ безпосередніми об'єктами окремих видів корупційного підкупу. I на цьому рівні вони можуть визначатись як установлений законодавством порядок (система) державного управління в тій чи іншій сфері або порядок виконання службових, професійних чи інших обов'язків.

\section{Література}

1. Ковальова І.С. Кримінально-правова характеристика підкупу працівника підприємства, установи чи організації : дис. ... канд. юрид. наук : 12.00 .08 ; Донец. юрид. ін-т МВС України. Кривий Ріг, 2018. 233 c.

2. Филимонов В.Д. Норма уголовного права. Санкт-Петербург : Издательство Р. Асланова «Юридический центр Пресс», 2004. 281 с. 
3. Дудоров 0.0. Проблемні питання кримінальної відповідальності за одержання хабара : автореф. дис. ... канд. юрид. наук : 12.00.08. Київ, 1994. 23 c.

4. Перешивко О.С. Об'єкт підкупу особи, яка надає публічні послуги (ст. 368-4 КК України). Национальный юридический журнал. Теория и практика. 2016. № 6 (22). C. 108-111.

5. Арманов М.Г. Об'єкт та предмет примушування до виконання чи невиконання цивільно-правових зобов'язань. Серія «Право» : Збірник наукових праць. 2006. Вип. 6. С. 38-44.

6. Костенко О.М. Модернізація доктрини сучасної кримінології у парадигмі соціального натуралізму. Вісник Асоціації кримінального права України. 2014. № 1 (2). С. 193-208.

7. Костенко О.М. Корупція в Україні у світлі політичної кримінології. Політичний менеджмент. 2009. № 1. С. 49-54.

8. Про засади державної антикорупційної політики на 2020-2024 роки : проект Закону України. URL: https: / / nazk.gov.ua/uk/departament-koordynatsiyiantykoruptsijnoyi-polityky_trashed/antykoruptsijnastrategiya
9. Пояснювальна записка до проекту Закону України «Про засади державної антикорупційної політики на 2020-2024 роки». URL: https://nazk.gov.ua/ uk/departament-koordynatsiyi-antykoruptsijnoyipolityky_trashed/antykoruptsijna-strategiya

10. Про національну безпеку України : Закон України від 21.06.2018 р. № 2469-VIII. Відомості Верховної Ради (ВВP). 2018. № 31. Ст. 241. URL: https://zakon.rada.gov.ua/laws/show/2469-19\#Text

11. Конституція України : Закон України від 28.06.1996 р. Відомості Верховної Ради України (ВBP). 1996. № 30. СТ. 141. URL: https: //zakon.rada.gov.ua/laws/show/254\%D0\%BA/ 96-\%D0\%B2\%D1\%80\#Text

12. Абрамов В.І., Ситник Г.П., Смолянюк В.Ф. Глобальна та національна безпека : підручник / за заг. ред. Г.П. Ситника. Київ : НАДУ, 2016. 784 с.

Михайлов М. В., https://orcid.org/0000-0002-5448-5379 аспірант відділу проблем кримінального права, кримінології та судоустрою Інституту держави і права імені В. М. Корецького Національної академії наук України 